Красинский Владислав Вячеславович

доктор юридических наук, член Общественного

консультативного научно-методического Совета

при ЦИК России

Krasinsky Vladislav V., P.H.D.,

the member of public scientifically-methodical

Council at the Central Electoral Commission of

Russian Federation

\title{
Государственный суверенитет: гносеологический аспект проблемы
}

Источник опубликования: Красинский B.B. Государственный суверенитет: гносеологический аспект проблемы // Современное право. 2015. № 7. С. 5-11. www.krasinskiy.ru

Аннотащия: В статье анализируется современная терминологическая система теории государственного суверенитета. Автор дает характеристику государственного суверенитета, раскрывает его понятие, сущность и содержание.

Ключевые слова: политическая власть, государственная власть, государственный суверенитет, национальный суверенитет, народный суверенитет, народовластие, суверенные права государства, суверенные обязанности государства.

In article modern terminological system of the theory of state sovereignty is analyzed. The author characterizes the state sovereignty, reveals its concept, essence and content.

Keywords: political power, state power, government, state sovereignty, national sovereignty, popular sovereignty, democracy, sovereign rights of State, sovereign obligations of State.

Мощь и эффективность государственной власти измеряется в первую очередь ее суверенностью. Проблемы государственного суверенитета всегда находились и продолжают оставаться в центре внимания отечественных и зарубежных государствоведов, политологов и философов. Усилиями ученых и государственных деятелей на протяжении нескольких столетий была разработана теория государственного суверенитета, которая внесла неоценимый вклад в обеспечение национальной общественно-политической стабильности, международного правопорядка, позволила усовершенствовать 
и приблизить к населению государственные институты власти, повысить их ответственность перед обществом.

В основе данной теории лежат дефиниции, выводные знания и доказательства, предложенные представителями различных политикоправовых и конституционных доктрин.

Теоретико-правовое исследование государственного суверенитета представляется логичным начать с изучения специфики государственной власти, характеристики свойств государственного суверенитета, раскрытия его понятия, сущности и содержания.

Особенности государственной власти связаны с тем, что она отделена от общества, распространяется на всех его членов и осуществляется специальным аппаратом управления и принуждения.

Как и другие разновидности публичной власти, государственная власть осуществляет руководство общественными делами. Но в отличие от предшествовавшей ей родоплеменной власти государственная власть возвышается над населением, является единственной по содержанию и организации суверенной властью в обществе и регулирует основные стороны общественной жизни, осуществляя свои властные функции по отношению ко всем субъектам, участвующим в управлении делами общества.

Политическая негосударственная власть не имеет аппарата управления и принуждения. Она обычно опирается на массовые движения или вооруженные отряды.

Как отмечает В.Е. Чиркин, "только государственная власть юридически уполномочена от имени всего общества применять легализованное и в большинстве случаев легитимное принуждение, насилие" [1, с.107].

Только государственная власть обладает юридически (иногда и фактически) верховенством, суверенным свойством, которое реализуется путем установления в обществе единого правопорядка, правоспособности государственных органов и общественных организаций, в наделении правами и обязанностями должностных лиц и граждан. Именно в верховенстве 
выявляется определяющее положение государственной власти по отношению к любым иным властным проявлениям. Никакие субъекты политической деятельности не могут длительное время противостоять суверенной государственной власти. В государстве не может быть нескольких государственных властей со своими институтами. Наконец, полновластная государственная власть вправе объявить любые общественные властные проявления вне закона.

Как отмечал государствовед В.С. Шевцов, "верховенствующее положение государственной власти в обществе реализуется прежде всего в установлении и претворении в жизнь системы правовых норм, основные особенности которых заключаются в том, что они: во-первых, являются прямым порождением государственной власти, воплощают ее политику; вовторых, обеспечиваются в своем применении в необходимых случаях принудительной силой государства; в-третьих, распространяются на все общество в целом. Устанавливая посредством правовых актов определенный порядок деятельности государственных учреждений, взаимоотношений между государством и гражданином, между различными ведомствами, организациями, предприятиями, определяя основные нормы поведения людей, государство организует экономическую, социально-политическую, культурную жизнь общества таким образом, чтобы обеспечить полное и своевременное удовлетворение объективно возникающих потребностей и способствовать его нормальному функционированию и развитию"[2, с.74].

В советский период верховенство как суверенное свойство государственной власти учеными-юристами рассматривалось в трех аспектах:

- через универсальность государственной власти, т.е. распространение её властной силы на всю территорию, всё население и все организации страны; 
- через полновластие (исключительность): возможность признания государственной властью ничтожным любого проявления всякой другой общественной власти;

- через наличие у государственной власти особых средств воздействия и принудительного механизма реализации государственных предписаний (законодательство, органы принуждения и др.) [3, с.49].

В настоящее время традиционный подход к пониманию суверенитета государства состоит в том, что наряду с верховенством в конструкцию суверенной государственной власти входит и её независимость, которая понимается как возможность государства самостоятельно решать свои внутренние и внешние задачи и функции [3, с.50]. Суверенитет государства в этом случае рассматривается как «специфический признак государства, выражающий верховенство государственной власти по отношению ко всем иным организациям и лицам в стране и независимость ее в сфере взаимоотношений данного государства с другими государствами» [4, с.80].

Если не относить верховенство государственной власти только к внутригосударственным делам, а её независимость - к межгосударственным отношениям (что вполне обоснованно), логическим следствием такой точки зрения выступает позиция, что никакие другие организации внутри страны и за рубежом не могут функционально заменить государство.

Отдельные юристы рассматривают независимость государственной власти не как самостоятельное свойство, а как необходимое условие верховенства. Автор не разделяет эту точку зрения, поскольку независимость как условие выступает внешним явлением объективной реальности, средой для существования верховенства, между тем как свойства суверенитета имманентно присущи ему. Справедливости ради следует отметить, что данный подход не получил широкой поддержки.

Таким образом, краткий анализ юридической доктрины и понятийнокатегориального аппарата современной теории государственного суверенитета позволяет сделать вывод о том, что государственный 
суверенитет непосредственно выражает сущность государственной власти через ее суверенные свойства - верховенство и независимость [1, с.107; 5, с.41; 6, с.55; 7, 45; 8, 21; 9, 39]. Только суверенная государственная власть способна самостоятельно решать любые внутри- и внешнеполитические задачи, обеспечивать реализацию своих властных полномочий в отношении всех субъектов права в пределах своей территориальной юрисдикции.

В структуре государственного суверенитета присутствует искусственная, на наш взгляд, конструкция, в соответствии с которой некоторые теоретики права выделяют внутренние и внешние аспекты суверенитета. Приверженцы данной точки зрения исходят из неоспариваемого посыла, что государственный суверенитет рассматривается как верховенство политической власти и законов внутри страны и за ее пределами, как независимость государства во внешних и верховенство во внутренних делах. Если же рассматривать направленность деятельности и вектор властных правомочий государства, то можно косвенно оценить его самостоятельность и полновластие.

В таком ракурсе суверенитет государства внутри страны (внутренний аспект суверенитета) выражается: в единстве и распределении государственной власти на всё население и общественные организации страны; в общеобязательности решений органов государства для всех, кого они касаются, на территории государства; в прерогативе, т.е. возможности отмены и признания ничтожным любого проявления другой общественной власти [9, с.39].

Суверенитет государства за пределами его территории (внешний аспект суверенитета) проявляется в способности государства выступать полноправным субъектом международного права, самостоятельно формировать и реализовывать внешнюю политику, защищать свою целостность и территориальную неприкосновенность и распространять свою юрисдикцию в пределах экстерриториальности. Внешний суверенитет неразрывно связан с иммунитетом государства от юрисдикции иностранных 
государств. Это означает, что суверенное государство не подчиняется органам власти иностранных государств. Суверенный иммунитет государства согласно доктрине международного частного права включает несколько элементов [10]:

- судебный иммунитет (неподсудность государства суду иностранного государства);

- иммунитет от предварительного обеспечения иска;

- иммунитет от принудительного исполнения иностранного судебного решения;

- иммунитет собственности государства - правовой режим неприкосновенности государственной собственности, находящейся на территории иностранного государства.

Логика внутреннего и внешнего суверенитета понятна. Иммунитеты государства встречаются в практике частно-правовых отношений с участием иностранного элемента. Международно-правовые аспекты суверенитета рассматриваются в рамках международного публичного права. Однако выделение дополнительных элементов в структуре конституционно-правовой теории государственного суверенитета представляется излишним, поскольку невозможно представить себе суверенное только во внутриполитических или внешнеполитических вопросах государство. Направленность полномочий государства также не является критерием суверенности государственной власти. Только системная взаимосвязь верховенства и независимости государственной власти, характер принятых высшими органами власти решений и мер по их практическому воплощению позволяют судить о наличии либо отсутствии реального государственного суверенитета. Поэтому большого практического смысла в вычленении внутреннего или внешнего суверенитета в конституционном праве не усматривается.

В терминологической системе теории государственного суверенитета на протяжении длительного времени различают государственный, народный 
и национальный суверенитет. Несмотря на тесную связь между ними, эти понятия различаются.

Если государственный суверенитет - это выражение сущности верховной и независимой государственной власти, то народный суверенитет следует определять как реальное экономическое, социальное и политическое положение народа, позволяющее ему обладать полновластием в обществе и государстве [2, с.77].

Поэтому народный суверенитет определяется как полновластие народа, т.е. обладание народом социально-экономическими и политическими средствами для реального участия в управлении делами общества и государства [11, с.300].

Некоторые юристы справедливо рассматривают народный суверенитет как качественную сторону власти народа в системной взаимосвязи с принципами конституционного строя. По мнению Б.С. Эбзеева, народный суверенитет есть скорее не сама власть, а важнейший организационнополитический и функциональный принцип конституционного строя государства, реализация которого обеспечивает верховенство и полновластие народа [12, с.54].

Национальный суверенитет - это реальная политическая, социальная, территориальная, культурная, языковая самостоятельность нации, которая проявляется в полноте суверенных прав нации и обеспечивает их наиболее полное осуществление. Суверенная нация самостоятельно решает вопрос о своей национальной организации и национально-государственном устройстве. Она вправе сохранять и свободно развивать свой язык, обычаи, уклад жизни, соответствующие национальные учреждения [2, с.78].

Народный и национальный суверенитет лежит в основе государственного суверенитета, поскольку именно государственный суверенитет выражает и гарантирует как волю народа в целом, так и каждой нации и народности в отдельности. 
В.А. Лебедев и В.В. Киреев справедливо отмечают, что «суверенитет государства представляет собой выраженный особыми политико-правовыми средствами суверенитет народа» [13]. Поддерживая данную точку зрения как идеальную, автор всё же склоняется к более реалистичному пониманию взаимосвязи народного и государственного суверенитета. Государственный суверенитет должен быть производен от народного, хотя далеко не всегда его полноценно выражает.

Трактовка государственного суверенитета как формы проявления народного суверенитета имеет следующие основания. Во-первых, государство как особая политическая организация общества призвана выражать волю народа и действовать в его интересах, решать общенародные дела. Подвергая справедливой и нередко острой критике отдельные государственные институты, следует осознавать, что другой организации, способной реализовать национальные интересы в полном объеме, просто не существует [13]. Только государство является официальным представителем всего общества. Во-вторых, именно народ располагает правом формировать аппарат государственной власти и воздействовать на него таким образом, чтобы в случае отклонения деятельности субъектов государственного управления от интересов народа привести ее в соответствие с такими интересами. Во-третьих, адекватное выражение народного суверенитета в суверенитете государства является решающим условием самостоятельности внутренней и внешней политики государства, еe эффективности и прагматизма. Именно независимый (суверенный) народ может наделить свое государство качеством суверенитета [14, с.76].

Любопытную аргументацию взаимосвязи государственного и народного суверенитета выдвинул В.В. Горюнов. Ученый справедливо указал ряд случаев, когда прямая связь между суверенитетом государства и суверенитетом народа прерывается. Это происходит тогда, когда система формирования государственного аппарата не требует выявления воли народа (например, в условиях абсолютной монархии) либо когда процедуры 
выявления его воли исключительно формальны и не позволяют обеспечить демократичность деятельности государственных органов (что имеет место, в частности, в тоталитарных государствах) [14, с.185].

Автор разделяет точку зрения С.А. Авакьяна о том, что «государственный суверенитет производен от народного суверенитета и является его логическим продолжением, служит тому, чтобы никакие внутренние и внешние силы не препятствовали выражению воли народа; тем самым государство становится защитником интересов народа, в том числе и на международной арене» [16].

А. Джагарян также чётко акцентирует внимание на недопустимости внешнего воздействия на волю народа: "верховенство и полновластие народа характеризуется недопустимостью какого бы то ни было внешнего воздействия, в том числе со стороны иностранных государств и организаций, на формирование, принятие и реализацию государственно-властных решений"[15, с.139].

Заслуживает поддержки позиция М. Соколова о том, что "вопросы властвования и политического преемства должны решаться исключительно внутри - без какого-либо внешнего вмешательства и уж тем более без прямого внешнего арбитража... Исключение внешних инстанций из решения внутренних политических вопросов всегда являлось принципом всех цивилизованных стран" [17, с.15].

Отдельного внимания заслуживает вопрос о сущности государственного суверенитета.

Поскольку сущность государства заключается в том, что оно выступает орудием власти тех или иных классов, сословий или социальных групп, то рассмотрение сущности государственного суверенитета следует вести по пути фактического использования государственной власти в интересах правящих слоёв и эффективности деятельности системы государственных органов по отношению к населению.

В таком контексте государственный суверенитет может служить 
оценочной характеристикой государственного механизма и существующего политического режима.

Провозглашение в конституции суверенитета народа и государства совсем не означает их реального наличия. В современном мире есть государства, в которых вся полнота и мощь власти, различные звенья государственного механизма направлены на обогащение и защиту коррумпированных чиновников, а централизованный бюрократический государственный аппарат, имеющий узкую социальную базу поддержки, для осуществления управления обществом прибегает к прямому насилию и подавлению. В то же время полновластие государства может успешно использоваться для развития политического, религиозного, национальнокультурного многообразия, расширения и реального осуществления прав и свобод граждан, поддержки независимых от государства и оппозиционных институтов гражданского общества, укрепление законности в деятельности государственных органов и учреждений.

Ни в коем случае не следует отождествлять государственный суверенитет и народовластие. В истории можно найти множество примеров, когда недемократические государства являлись суверенными в подлинном смысле этого слова. И напротив, значительное число стран с давними демократическими традициями государственным суверенитетом не обладали и не обладают. При этом как суверенные, так и не обладающие реальным суверенитетом государства могут проводить социально ориентированную политику в сфере образования, здравоохранения, культуры, стимулировать технический прогресс, обеспечивать занятость трудоспособного населения. Это обусловлено тем, что современной тенденцией политической жизни любого государства является стремление правящих кругов иметь широкую социальную поддержку проводимой политики и придать своему правлению конституционный характер. В отличие от ранних исторических типов государств (рабовладельческих и феодальных) правящие силы современных государств используют не открытые формы осуществления политического 
господства подавления, а замаскированную защиту своего политического, экономического и идеологического влияния.

Другой важный момент заключается в том, что коррупционная пораженность, нарушения законности в деятельности государственного механизма и недоверие населения представительным органам власти (что может присутствовать как в демократических, так и в недемократических политических режимах) существенно затрудняют формирование и выражение воли народа, реализацию национальных интересов.

Если сущность государственного суверенитета означает целевую направленность фактического использования верховенства и независимости государственной власти правящими слоями, то содержание государственного суверенитета составляет совокупность прав, необходимых для реализации функций государства. Именно в реализации этих правовых возможностей начинают действовать суверенные свойства государственной власти. Другими словами, чем шире спектр применяемых государством полномочий по реализации своих внутренних и внешних функций, тем больше оснований вести речь о глубоком наполнении реального содержания государственного суверенитета.

Следует учитывать, что в идеале суверенными правами государства являются только такие права, на осуществление которых его уполномочил народ. Иными словами, суверенные права государства предстают в качестве своеобразной проекции суверенных прав народа [14, с.184]. Но для этого население государства должно принимать активное участие в формировании органов власти и влиять на деятельность всех звеньев государственного механизма, что достижимо далеко не везде.

Особенность суверенных прав государства состоит в том, что:

1) кроме государства никакой другой субъект права их реализовать не может; 
2) речь идет о возможной деятельности государства, которая в разных социально-экономических условиях может отличаться своим содержанием и внешним проявлением.

В традиционный перечень исключительных суверенных прав государства входят: эмиссия, осуществление правосудия и исполнение наказаний, право решать вопросы войны и мира, участие в межгосударственных объединениях, помилование и амнистия, монополия на правотворчество и налогообложение и др.

Автор согласен с В.В. Горюновым в том, что «не может быть некоего универсального и заранее данного для всех государств перечня суверенных прав. Каждое государство в зависимости от конкретных обстоятельств может актуализировать те права, которые необходимы для выполнения его функций в конкретной исторической ситуации, что говорит о неисчерпаемости суверенных прав» $[14$, с.185].

В соответствии с теорией правоотношений, особым участником которой выступает государство, суверенные права предполагают корреляцию с суверенными обязанностями государства. В связи с этим помимо каталога суверенных прав содержание государственного суверенитета предполагает наличие обязанностей суверенного государства.

К их числу можно отнести следующие обязанности:

соблюдение конституции и подчинение государственных органов, госслужащих и должностных лиц праву;

обеспечение эффективной борьбы с преступностью (невзирая на материальное и должностное положение, национальную принадлежность и вероисповедание преступников);

обеспечение военной, продовольственной, финансовой, конституционной и других видов безопасности;

обеспечение территориальной целостности государства;

осуществление активной разведывательной и контрразведывательной деятельности; 
защита государственной власти (включает в себя обеспечение безопасности выборов, государственную защиту должностных лиц, судей, сотрудников правоохранительных органов, недопущение захватов и блокирования конституционных органов власти и местного самоуправления, недопущение создания и функционирования, пресечение деятельности альтернативных органов власти, незаконных вооруженных формирований, экстремистских структур и др.);

осуществление дипломатической и правовой защиты своих граждан независимо от их местонахождения;

уголовное преследование и сопровождение выдачи иностранных граждан, лиц с множественным гражданством и апатридов, совершивших преступления в отношении граждан государства за рубежом и на территории государства;

осуществление военной защиты своих граждан в случае агрессии иностранного государства;

оказание гуманитарной помощи своим гражданам, находящимся в зоне внутренних вооруженных конфликтов, в районах чрезвычайных ситуаций;

эвакуация своих граждан из зон вооруженных конфликтов и районов чрезвычайных ситуаций.

Так же, как и перечень прав, суверенное государство вправе корректировать и дополнять перечень своих суверенных обязанностей перед населением.

Рассмотрение гносеологических вопросов государственного суверенитета, его предметного статуса позволяет сделать следующие выводы:

1. Суверенитет юридически закреплен за каждым государством, а фактически им обладают немногие.

2. Критерием наличия суверенитета является способность государства решать любые задачи в сфере реализации внутренних и внешних функций 
государства и обеспечивать исполнение принятых государственно властных решений.

3. Суверенитет не зависит от формы государства. Даже несмотря на то, что большинство современных стран провозгласило себя демократическими государствами с республиканской формой правления.

4. Суверенитет является динамичной характеристикой государства. Он может быть подорван и утрачен. В силу этого государственный суверенитет нуждается в защите.

\section{Список использованных источников и литературы:}

1. Чиркин В.Е. Государствоведение. М.: МПСУ, Воронеж, 2012. С. 107.

2. Советское государственное право. М.: Высшая школа, 1978. С. 74.

3. Проблемы теории государства и права / Под ред. С.С. Алексеева. М.: Юрид. лит., 1979. С. 49, 50.

4. Тихомиров Ю.А. Суверенитет в условиях глобализации / Суверенная демократия в конституционно-правовом измерении. Сб. статей и материалов. М.: Рос. газ., 2007. С. 80.

5. Теория государства и права / Под ред. С.С. Алексеева. М.: Юрид. лит., 1985. C. 41;

6. Теория государства и права / Под ред. В.К. Бабаева. М.: Юристъ, 1999. C. 55.

7. Лазарев В.В., Липень С.В. Теория государства и права. М.: Спарк, 2004. C. 45 ;

8. Сырых B.M. Теория государства и права. М.: ЗАО Юстицинформ, 2005. C. 21.

9. Теория государства и права / Под ред. М.Н. Марченко. М., 1987. С. 39.

10. Международное частное право / Под ред. Г.К. Дмитриевой. М., 2002.

11. Румянщев О.Г., Додонов В.Н. Юридический энциклопедический словарь. М.: Инфра-М, 1996. С. 300.

12. Эбзеев Б.C. Личность и государство в России: взаимная ответственность и конституционные обязанности. М.: Норма, 2011. С. 54.

13. Лебедев В.А., Киреев В.В. Концепция суверенной демократии: парадигма, проблемы, перспективы // Конституционное и муниципальное право. 2007. № 5.

14. Горюнов B.B. Суверенитет и демократия - основополагающие принципы конституционного строя России / Суверенная демократия в конституционно-правовом измерении. Сб. статей и материалов. М.: Рос. газ., 2007. C. 184. 
15. Джагарян A.A. Концепция суверенной демократии в конституционном измерении / Суверенная демократия в конституционноправовом измерении. Сб. статей и материалов. М.: Рос. газ., 2007. С. 139.

16. Авакьян C. А. Точка отсчета - народ// Рос. газ. 2006. 28 октября.

17. Соколов M. Суверенитет и свобода / Рrо суверенную демократию. Сб. М.: Европа, 2007. С. 13, 15. 